
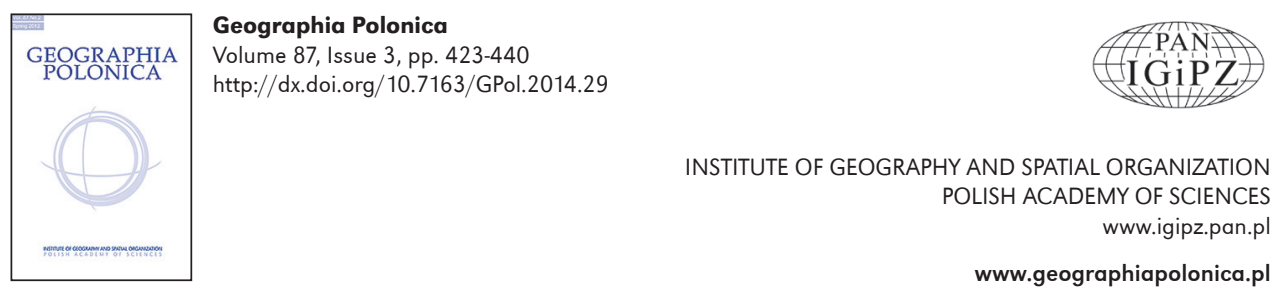

\title{
POLAND AND EASTERN EUROPE IN THE EUROPEAN UNION
}

\author{
Giuliano Bellezza \\ Vice-President of the International Geographical Union \\ University of Roma La Sapienza and Tuscia (Viterbo) \\ Piazzale Aldo Moro 5, 00185 Roma: Italy \\ Professor Emeritus \\ e-mail: giuliano.bellezza@uniroma1.it
}

\begin{abstract}
Pope John Paul II wrote that Poland is "a Republic peacefully including many Nations, many Cultures, many Religions". Somehow Norman Davies was more critical when he entitled his two volume history as God's playground: A history of Poland. The Author of this paper feels rather uncertain about these descriptions. Certainly the neighbouring states have been very active in the 'playground', but the population has never been invited to play, and, lest we forget, look what happened to the Jewish inhabitants. Only in 1989, a long time after WW2, did East European states gain their full independence, and then their economic backwardness compared with Western Europe suddenly appeared in its full dimension. After years of diplomatic discussions, Poland and seven other East European states could officially join the European Union in 2004. This year was chosen for a first socio-economic comparison between the old and the new members of the EU. It was no surprise at all; the situation in the new members was by far the worst, even when compared with the less wealthy older ones. The second comparison relates to 2007 when the new members entered the Schengen Area, a compulsory clause for new members of the EU. Though remaining strong, differences were slowly decreasing. But a global crisis was beginning, and the crash officially came in September 2008 (with the bankruptcy of Lehman Brothers). That's why the 3rd comparison, relative to 2012, gives puzzling results. The economic crisis has, without a doubt, been truly global, and from 2007/2008 to 2012 the figures got worse everywhere. But the impression changes when comparing 2012 to 2004: generally speaking, GDP has gone up in the old members but has been completely nullified by inflation. Not so in the New Member States where people certainly have more money now than they did before accession. In the first years after accession many workers tried to move westbound, but now a good number are coming back.

I have dedicated greater importance to Poland, for obvious reasons, and to Italy. These are two countries which are traditionally friendly, and the more so after the election of John Paul II. In conclusion, all in all, accession has been a good choice for the new members, but to progress further stronger cooperation is needed.
\end{abstract}

\section{Key words}

Human Development Index (HDI) • migration • Poland • Italy • European Union 


\section{Introduction}

After the collapse of the Soviet Union and the unification of East and West Germany, many Centre and East European states started diplomatic talks to join the European Union (EU); in 2004 the largest ever accession process was eventually ratified: 10 new members joined including the 2 island states of Cyprus and Malta. These last two are not considered in this article, which is dedicated to the economic opportunities that opened up for the 8 East European states through freer communication by land. Actually, in order to fulfil the accession conditions the new member also needed to prepare to enter in the Schengen Area in the years that followed, a commitment accomplished in 2007. Hence, the question addressed in this article is: did the decision to join the union influence the later socio-economic development of the East European states? And, perhaps, also of the existing EU members?

The new members were (in alphabetical order) the Czech Republic, Estonia, Hungary, Latvia, Lithuania, Poland, Slovakia and Slovenia. In order to make comparisons with the older members of the EU, I have chosen Austria, Denmark, Netherlands, Greece, Italy and Spain: the first 3 representative of the wealthier states, the others representative of the less developed part of the Union, which is the Mediterranean area. To honour the host country of the IGU 2014 Conference, much space will be dedicated to Poland. Among the older members of the EU, some more attention will be reserved for Italy which, apart from being my own country, was one of the 6 founders of the initial Communities and the first Treaties which were signed in Rome in 1957.

It is commonly said that great individuals influencing history have too often made bad mistakes due to their poor knowledge of geography. I argue that the same thing can be said about poor knowledge of history, but this is not particularly true in the case of Poland. The powerful states surrounding Poland had a good knowledge of its geography and history: they simply wanted to suppress it as an independent state. In any case, if one tries to explain its geography today, a good knowledge of its landforms, climate, agricultural, or mineral resources is far from enough. All these, certainly, should be taken into due consideration, but one could never reach a sound conclusion without studying in advance the very troubled historical events which make up its history. The fact is that in this case, many different ethnic groups were involved in the history of the same territory with changing alliances and rivalries between them, particularly when, in the most recent centuries, nationalistic attitudes gained in importance.

The English geographer and politician Mackinder (1904) presented his paper The Geographical Pivot of History in a Conference in the Royal Geographical Society in London. In his imagination, the central 'Heartland' giving the best possibilities to dominate the world was occupied by Russia. Applying his theory two centuries earlier, one would have probably mentioned Poland as the strongest power occupying a large part of the Heartland. And, as everybody knows, the Age of Partitions, so tragic for Poland, began only some decades later.

Only after WW1, did the victorious Powers want to establish a new and ephemeral Second Polish Republic (II Rzeczpospolita, November 1918) in a small part of what had been called the Heartland less than 20 years earlier. A very peculiar state indeed, with six different currencies, five different kinds of Regional Administration and three different legislative codes; a territory where the officers of the army were forced to give orders in four very different languages, and the railways needed to be adapted to two different gauges.

All this said, the really terrible times were still to arrive less than 20 years later, when a new partition was decided, this time between Nazi Germany and the Soviet Union just before WW2. But within a very few years the everlasting Poland was back to life once again soon after the war. This time the boundaries were shifted about $250 \mathrm{~km}$ westward 
to the river Bug (Davies 2005-2006'; Morawski 2014), with Poland losing nearly half of its territory: all in all, some tens of thousands square $\mathrm{km}$ were passed to Ukraine, Belarus and the Baltic Republics (especially Lithuania), while a part of its territory was gained at the expense of Germany. After some years, the distribution would appear more reasonable and realistic from the ethnic point of view but this had been obtained with much suffering, and with displacements involving a very large number of people forced to abandon houses and properties, in many cases during episodes of real pogroms (Eberhardt 2002).

As a result, the new Rzeczpospolita Polska had to change its name, adding the adjective Ludowa (People's) to its name - Polish People's Republic (Polska Rzeczpospolita Ludowa) and, above all, most importantly, remaining under the strong influence of the USSR until 1989, when a new change happened. This time the event didn't follow war, but it was the successful outcome of strong, though not so violent, riots and popular revolt. The adjective Ludowa was removed from the official name, and ever since several political parties participated in regular elections, with alternating victories. The new Poland, as well as many other States until then subject to the former Soviet Union, regarded the European Union with careful attention for several reasons. The $E U$ is, in fact, the final outcome of a series of Treaties originally signed in May 1957 and officially implemented on 1 January 1958 by France, Germany, Italy, Belgium, The Netherlands, and Luxembourg. The well expressed and realised goal of the Treaty of Rome was to avoid any further war on European territory. At the time, many European States were still located east of the so called 'Iron Curtain'; only in 2004, when the Curtain was no longer in existence, could some of these countries join the EU. In this article an impression of the situation is given as perceived by an Italian observer 10 years after accession.

\footnotetext{
${ }^{1}$ Among dozens of good texts on the history of Poland, a most outstanding one is Davies (2005-2006). This is the source of the historical information if not advised otherwise.
}

\section{The italian problem: From a country of emigration to a country of immigration}

The idea of a federation of European States has been present in Italy since the 1930s and took its completed form in the Manifesto di Ventotene, at a time when the authors (Spinelli \& Rossi 2006) were imprisoned by the Fascist Government on the little island of Ventotene, which explains the title. After the devastation of WW2, six of the more devastated countries of Western Europe decided to adopt a joint agreement on economic matters; they were France, Germany, Italy, Belgium, the Netherlands and Luxembourg. The first achievement was the European Coal and Steel Community established by the Treaty of Paris (1951), followed in 1957 by the European Economic Community and the European Atomic Energy Community founded in Rome (1957). Later, several other states asked to join and, after a series of successive enlargements, today's European Union is formed of 28 members with others still on the waiting list.

The economic results were very good from the beginning (Bellezza 1974), so that by the 1960s Italy had enjoyed a period of economic growth and general well-being. Women of the upper and middle classes abandoned the traditional position of looking after the house, finding a job which allowed them to pay a housekeeper and save money for their own expenses.

The demand for housekeepers was rapidly satisfied by the immigration of women from Catholic regions (Philippines, Cape Verde, Latin America, Kerala and other Indian states) and from former African Colonies through the intermediation of missions operating there and parishes in Italy. They were quiet people, giving no trouble of any kind, finding work in rather wealthy families so that for many years no one in Italy viewed immigration as a danger. It took a long time to realise that the former country of emigration was transforming into one of immigration, a country where foreign people began to be considered 
not only as wealthy tourists, but with certain suspicion. This was mainly because unemployment was now growing in Italy, but also because the fertility of Italian women was falling dramatically. A population that was, until the 1970s, among the fastest growing in Europe was already, by the 1980s, among the slowest (EU 2013).

On the side of immigration, the situation changed again in the late 1970s when men also began to arrive in Italy. The first male immigrants came from the Mediterranean African coast, landing in Sicily to become agricultural seasonal workers during the harvest period, or taking any job in the Sicilian fishing industry, whether on boats or in shipyards (Bellezza 1978). Numbers were not high, and the majority of immigrants only remained for a few months, possibly coming back again for the next work season.

During the 1990s the economic situation in Western Europe was getting worse and the unemployment rate was growing when, approaching the 3rd Millennium, Italy suddenly became the target of poor seaborne refugees escaping from Albania. This deadly phenomenon ended after some years thanks to an agreement in which some Italian firms expanded into Albania, where they enjoyed favourable conditions and employing local workers (Mehillaj 2009).

But some years later the illegal immigration to Italy became a torrent when refugees began to arrive by sea from the African Mediterranean coast and the monthly number grew from hundreds to thousands. Eighty per cent of the emigrants were boarding on some hidden shore of Libya, bound to some of the many hidden moorings of the southern coast of Lampedusa, a very small island. But the majority of the old boats were shipwrecked on the open sea and their occupants were rescued by Italian fishing boats or, after some months, by the Italian Coast Guard (Amnesty International 2006).

These desperate immigrants weren't looking for a 'better' life, just life itself was more than enough for them. Escaping from local dictatorships more or less disguised as pseudo democracies, they were entitled to ask for the status of political refugee. While this was certainly true for many of them, in fact some people had different, not political reasons. Nevertheless, no one could argue that escaping from poor third world countries because of famine, droughts, and starvation conditions are not serious reasons. Moreover, once sent back to their homelands, these immigrants were certain to receive severe punishment and find it difficult to survive .

Many of them arrived with their family and, though boarding mainly from Libya, were also escaping from the Saharan states from the Atlantic to the Red Sea. Hundreds, possibly thousands of people died during the desert crossing and the drama continued after they boarded the boats with a risk of shipwreck (Belezza 2009). According to HRW and the Italian Ministry of Interior (HRW 2006), the figure for irregular landings in Sicily in the period 1999-2008 grew from 1,973 to 35,540 per annum. Casualties began with dozens, then hundreds, per year, and are now measured in thousands. A short hiatus followed the so-called Arab Spring in the Southern Mediterranean, but in a couple of years the deadly voyages started anew.

Italy tried to identify the illegal immigrants to send them back to their native countries, but only a very small number of these immigrants had documents because during the travel the majority had lost all their ID documents and no one could find the native country to repatriate them to. Many refugees still remain in gathering points, little different from gulags. It is undeniable that Italy has made an incredible number of mistakes and mistreatments of the immigrants, but it must also be admitted that the human flow from Africa to Europe is not a local problem. It is a relentless, unstoppable process of global importance, bound to continue for a long time into the future. The Italian request to the EU to consider this problem on a continental scale is not only reasonable but totally rational from the geographical point of view.

Furthermore, after 2004 another flow expanded to levels never before seen in Italy: 
immigration from the new members of the European Union. In this situation, the Italian population once again started to increase, but this time the demographic growth was due to immigration and an influx of refugees. At the same time the demographic growth of Catholic Italians was slowing, and they were also somehow discovering how to be racist.

Almost everywhere in Europe populations remained quite stable, in the 1990s, in some states they were diminishing, and only in a few cases were they still growing: in Poland, to give but an example, there was a yearly growth around $0.4 \%$. For people wanting to emigrate from there, Germany and France had previously been the most desired destination but now, thanks to the presence of Pope John Paul II, Italy was seen as an attractive possibility. Until the late 1980s the numbers of Polish residents in Italy and France were similar, only because many families who had emigrated to France decades before were no longer classified as Polish, having acquired French citizenship. But during the 1990s the flow to Italy increased so that when in 2004 Poland became a member of the EU, the number of Polish residents in Italy was 66,000, nearly double that in France $(34,000)$; to complete this information it should be remembered that Germany (with 317,000 Polish residents) was still by far the preferred destination (Golemo et al. 2004).

\section{Enlargement of the European Union in May 2004}

On 1 May 2004 the EU finally ratified a substantial increase in its size with the accession of 10 countries. The acceptance of these countries hadn't been a rapid decision for several reasons, economic as well as diplomatic. Some years before, for example, the reunification of Germany had provoked economic difficulties, but all the persons involved were in favour. However even some of those who were in favour of reunification continued also, in spite of this, to wonder about the longterm cost of the operation. Now the situation was the opposite, and in 2004 many EU citizens simply didn't want to support this kind of cost at all.

Trying to explain this situation one needs to consider the different points of view of the new members, the old members, and the major powers, USA and Russia. All new members, and their populations, for certain wanted to join, for obvious reasons. Even with the USSR domination over and Russia's aggressiveness seemingly reduced, the fear of some east-borne danger never disappeared. The rather large buffers of Belarus and Ukraine were not seen as completely secure. Entering the EU now appeared to make them part of an entity well respected not only for freedom, democratic conditions, wealth, and affluence, but also at the same time completely sure of itself against any aggression.

In addition to all this, these states had all been severely injured by the Nazi occupation, and the feelings of resentment against Germany hadn't disappeared. However, dozens of years of too strong 'protection' by the USSR had nearly healed all the Nazi wounds.

Among the old members, opinions were not as unanimous. The first positive argument arose some years after the fall of the Berlin Wall; the total, complete absorption of the old Iron Curtain zone. The GermanyUSSR border for half a century had only been a strip of barbed wire and walls just a few metres wide. Now it had been enlarged to a buffer zone of allied or independent states about 2,000 km wide. Apart from the Germans, the other EU populations were not totally convinced about enlargement. Given the better economic conditions of the older members, there was a fear of a possible invasion of East Europeans seeking jobs: a danger, because the local economic conditions, though better than those of the new members, were not improving. In trivial terms, the economic cake was only growing a little, but the number of diners was increasing disproportionally. The individual slices in the future were bound to get smaller. In politics, the new members were not yet 
confident that the cold war had ended and were feeling much more at ease under the umbrella of NATO. The EU states, on the other hand, were in some cases suffering, when obliged, as NATO members, to participate in wars launched by the USA with its preeminent interest and were obliged, in normal times, to comply with the USA's economic pre-eminence.

What about the Big Powers? Russia wasn't happy at all, not so much for the loss of the states becoming new members of the EU, they were concerned about those that could become the next possible applicants to join the EU, Belarus and the Ukraine, especially the second. If a personal thought is allowed, one might comment that while Ukraine is now experimenting, it is possible to see how careful the EU has been to avoid not only conflict, but any kind of direct confrontation with Russia.

Back to 2004 and what the USA was thinking about EU enlargement. The EU was certainly growing larger, but its area still remained less than 4 million $\mathrm{km}^{2}$, only $40 \%$ of the size of the USA's nearly 10 million $\mathrm{km}^{2}$ and with many fewer mineral resources. Taken as a whole the EU enjoys a milder climate but from an agricultural point of view, the USA can obtain a large production from its tropical areas. Better known as an industrial power, USA has been by far the largest agriculture producer and exporter (and still is). Different again was the change in relation to population: the EU had grown from 270 million to 445 million, and so clearly had surpassed the USA (290). Strategically this was not very important, since wars were no longer a question of infantry. In addition it only took a short time to realise that the new entrants to the EU often seemed to be supporting the USA's global economic policies rather than those of the EU. In this yin-yang reality, it was difficult to understand, at that time, that the same USA was wary about entering into strong confrontation with Russia. No danger happened with the accession of the East European States in 2004 to the Western block. But it should be noted that in the years that followed Russian minorities began to complain about discrimination against minorities in Estonia and Latvia ${ }^{2}$.

\section{Poland's situation at the moment of accession}

A detailed analysis shows that in all large areas development is not uniform: in other words, statistical analysis clearly demonstrates that there are zones with different levels of development. In Poland a great deal of emphasis is often given to the economic difference between two main zones roughly divided by a diagonal line: a more developed North-Western zone and a less developed South-Eastern one. The differences are not only economic, but also, if not mainly, cultural. To understand these differences we need to obtain a deeper insight into them ${ }^{3}$.

In the 1930s, the time of the Rzeczpospolita Polska, the population of Poland was nearly $70 \%$ of Polish mother tongue; in the SE

\footnotetext{
2 This controversy is still continuing in Estonia, as Russia claims the Estonian habit of considering $\mathrm{Na}$ zism as equivalent to Communism is unfair, and this leads to the accusation that the same Estonian government is acting as a fascist one. In fact, while this is only propaganda, the presence of the extreme right and anti-Russian movements in Estonia is undeniable. In favour of the Russian minority's view is van Elsuwege (2004). On the other hand, there is nothing to reproach the Estonian Government about according to the UNDP Report (2011). Also problems in Latvia, as exposed in http://on.rt.com/pu5r41, are mainly based on language discrimination. The opponents won the referendum held in 2012 on whether to adopt Russian as a second official language by a large margin, but more than $10 \%$ of the population couldn't vote as they were not yet holders of a definitive status as citizens (CECOL 2012).

${ }^{3}$ Apart from Davies (2005-2006) quoted in note 1, much of the following information has been taken from the very interesting February 2014 issue of the Italian monthly magazine Limes, dedicated to "Polonia, I'Europa senza l'Euro" (Poland, Europe without Euro), with interviews with Radosław Sikorski, Adam Michnik and Krzysztof Szczerski in addition to articles like Paolo Morawski, Poland's Geopolitical Atlas; Danuta Hübner, Poland in the euro, but not immediately; Rafał Sadowski, Poland is a central European Country, not only because of Geography; Wiesław Władyka, Politics after 1989; all titles translated; all the texts are in Italian.
} 
Ukrainian was spoken and the 9\% of Jews, speaking Yiddish, were dispersed all over the country. By the end of the decade, in a Poland divided by Germany and the USSR, there were, besides Polish, Ukrainian and Jewish, many more ethnic minorities. Some years later, after WW2 and the big westbound transfer, percentages had changed again, but the ethnic minorities in what was now Polska Rzeczpospolita Ludowa were all present, though in small numbers. But there had been a terrible change: after the Shoah, the Jewish percentage was close to zero, and in the first years following WW2 things were certainly not easy. In fact, all the ethnic components of Poland had to suffer displacements, some of them on a 'voluntary' basis: thousands of Germans to Germany (East, and possibly West), Ukrainians to Ukraine and so on. In all these cases, the local people were more than glad to take the land and 'help' the movements. A series of very merciless forced displacements took place in a sort of multi-ethnic cleansing: all minorities had some reason to hate many of the others, and vice versa (Eberhardt 2002).

Under the protection of the USSR there was an easy way to eliminate people, simply denouncing a family or a group of persons saying that they had given help to the Nazis some years before, or that they were against communism.

Poland's general attitude toward the rest of the world is filtered by their attitude towards Germany and Russia: history fully explains this Polish feeling (100 years ago the Austro-Hungarian Empire would also have been cited). In popular memory, Poles have been paramount in heroism combating both Nazism (particularly in the Warsaw Uprising) and Communism for years, with thousands of martyrs in the several Nazi killing fields, not to mention in the massacre by Russia in Katyn in 1940 (David 1993).

Germans are considered evil for the killing fields (with one representing them all, Auschwitz-Birkenau), but are well respected for their suffering in the inhuman bombing in Dresden and for the post-war forced displacement from their traditional northern settlements in Pomerania, Silesia, and Masuria. Consideration of the heroic behaviour of the Germans in the critical battles of Stalingrad and Leningrad runs rather counter to popular thinking in Western Europe. And this takes us to Polish considerations toward Russia. The crucial role of the Red Army in the victory against Nazi Germany is deeply buried under the memories of the years preceding and following WW2. The Polish remember that the Red Army gave very little help to the Warsaw Uprising and, in addition to the episode in Katyn, there is the strong memory of the Augustów episode where hundreds of Poles were executed on the basis of doubtful accusations of being anti-communist rebels. But the more informed historian also remembers that in WW1 about 20,000 Russian soldiers died of hard work and starvation in the prison fields of Poland.

The half century under USSR's protection produced the current division into two zones: the North West has been influenced by admiration for the development of the Federal Republic of Germany, while in the South-East the dominating feeling was a strong enmity for Russia. Needless to say religion was exerting a powerful influence; in the North-West of Poland the very Catholic Polish maintained good relations with the Germans, Protestant as well as Catholics. Relations were not as good in the South-East, strangely enough because here is the region of the Eastern Catholic Churches, in full communion with the Pope in Rome, but self-governing with their own peculiar rites. Jealousy and conflicts were (and still are) strong between the Roman, Orthodox, Uniate, and Byzantine churches leading each of them to strictly traditional rules.

Adding geography to history, it is rather easy to understand the difference between the traditional, agricultural, conservative South-East and the more industrial, innovative North-West. From the ethnic point of view, the last Rzeczpospolita Polska, no longer Ludowa, had never been so Polish: out of 38.5 million, $97 \%$ were Polish; some 
more than 400,000 were Germans (Silesians, and Kashubians), followed by 50,000 Ukrainians; 47,000 Belarusians and lesser numbers of Roma, Russians, Lemks, Lithuanians, Armenians, Czechs, Slovakians, and Tatars (GUS 2012; Morawski 2014). There has been some protest, arguing that the Census was too based on spoken language, but this couldn't affect the real situation too much, and what is never stressed enough is the near total demise of the Jewish inhabitants. Luckily enough, the names of the minorities told more about their location, and nearly all the citizens were in fact usually Polish speaking, entertaining good relations with their neighbours ${ }^{4}$.

\section{Different zones are also present in the European Union}

Whatever the economic system the presence of zones with different levels of development is rather unavoidable in large regions. In 2003-2004, when the new members were joining, all of them, as well as the EU itself, were divided and in some cases more than two zones were detectable. Italy was, and still is today, a good example of tri-partition. The same EU was clearly showing two different zones of higher and lower development. When the new members joined, everybody knew that, excluding Cyprus and Malta, these two groups of old members really formed different zones, each made up of coterminous States. But everybody also knew that the new members were going to become a third EU zone: a less developed one. This is clear in the next table showing the main data at the time of passage from 2003 to 2004, a few months before accession took place. States are itemised in alphabetical order. Austria, Denmark and the Netherlands are representative of the more developed EU; Greece, Italy and Spain represent what was the less developed one, becoming in 2004 representatives of the

\footnotetext{
${ }^{4}$ John Paul II (2004) described Poland as a Republic peacefully including many Nations, many Cultures, many Religions.
}

medium one, leaving the lower position to the new members.

It is meaningless to compare area, population and density, while little importance can be assigned to the number of economically active inhabitants: more important, in this case, is the unemployment rate. Great importance can be assigned to State expenditure for Education and Health, while the key data are income per inhabitant and the more substantial Human Development Index.

At first glance, income per capita of the new members varied from $\$ 4,000$ to $\$ 8,000$, with the exception of Slovenia, reaching $\$ 14,000$. But their mean level was only one third of that of the EU, and the exceptional Slovenia remained lower than Spain, very distant from the EU mean (though this figure already included the new members); not to mention the mean of the high level zone, which is above $\$ 32,000$. The maximum GDP among the States mentioned in the table is Denmark, above $\$ 39,000$, but this is far from the record of Luxemburg, which has more than $\$ 52,500$ : a difference more than twice the mean revenue of the new members. This is really too much in a reasonable Union, but only about $0.1 \%$ of the population is concerned, so it is really negligible. Not even one of the more populated states (Germany, France, United Kingdom and Italy) achieved the figure of Austria (Tab. 1).

Inflation was rather peculiar, given that the Baltic Republics and Czech Republic were below the EU mean, while in the other States it was about two or three times higher. The unemployment is also difficult to interpret. In general the low rates, better than the EU mean, were only present in the richest states, while the workers in the medium and low income states had the worst conditions, but with some exceptions: the lowest level among the medium and low income states was registered in the Czech Republic, and good conditions also existed in Hungary and Slovenia.

As regards $\mathrm{HDI}$ values, since regular estimates of this index started to be made, European states have always been among those with the highest values in the world, but in the 
Table 1. Main statistical data of the states taken into consideration, 2003-2004

\begin{tabular}{|c|c|c|c|c|c|c|c|c|c|c|}
\hline & $\begin{array}{c}\text { Area } \\
\text { (thous. } \mathrm{km}^{2} \text { ) }\end{array}$ & $\begin{array}{l}\text { Population } \\
\text { (thous.) }\end{array}$ & $\begin{array}{c}\text { Population } \\
\text { density } \\
(\text { per km²) }\end{array}$ & $\begin{array}{l}\text { Urbanization } \\
\qquad(\%)\end{array}$ & $\begin{array}{c}\text { GDP } \\
\text { (USD p.c.) }\end{array}$ & $\begin{array}{l}\text { Inflation } \\
(\%)\end{array}$ & $\begin{array}{l}\text { Unemploy- } \\
\text { ment rate } \\
(\%)\end{array}$ & $\begin{array}{c}\text { GDP for } \\
\text { education } \\
(\%)\end{array}$ & $\begin{array}{c}\text { GDP for } \\
\text { health care } \\
(\%)\end{array}$ & $\mathrm{HDI}$ \\
\hline EU & 3,970 & 445,662 & 112 & 73 & 21,283 & 2.7 & 8.4 & 4.8 & 7.6 & - \\
\hline Czech Republic & 79 & 10,203 & 129 & 75 & 8,242 & 0.6 & 7.5 & 4.4 & 7.4 & 0.868 \\
\hline Estonia & 45 & 1,356 & 30 & 69 & 4,863 & 1.7 & 10.1 & 7.6 & 5.5 & 0.853 \\
\hline Latvia & 65 & 2,325 & 36 & 60 & 3,984 & 3 & 10.5 & 5,9 & 5.9 & 0.823 \\
\hline Lithuania & 65 & 3,346 & 53 & 70 & 5,126 & 0 & 12.7 & 7.3 & 6.0 & 0.842 \\
\hline Hungary & 93 & 10,117 & 109 & 65 & 8,378 & 4.7 & 5.9 & 5.2 & 6.8 & 0.848 \\
\hline Poland & 313 & 38,199 & 122 & 62 & 5,320 & 8 & 19.2 & 5.4 & 6.1 & 0.850 \\
\hline Slovakia & 49 & 5,379 & 110 & 57 & 5,752 & 8.5 & 17.1 & 4.1 & 5.7 & 0.842 \\
\hline Slovenia & 20 & 1,997 & 99 & 50 & 13,978 & 5.9 & 6.5 & 13.3 & 8.4 & 0.895 \\
\hline Austria & 83 & 8,079 & 96 & 67 & 30,349 & 2.9 & 4.4 & 5.8 & 7.9 & 0.934 \\
\hline Denmark & 43 & 5,384 & 125 & 85 & 39,152 & 2.5 & 5.6 & 8.3 & 8.4 & 0.932 \\
\hline Netherlands & 42 & 16,224 & 391 & 90 & 31,524 & 2.6 & 5.3 & 4.8 & 8.9 & 0.942 \\
\hline Greece & 132 & 11,018 & 83 & 61 & 15,552 & 3.8 & 9.8 & 3.8 & 9.4 & 0.902 \\
\hline Italy & 301 & 57,888 & 192 & 67 & 24,998 & 2.8 & 8.7 & 4,7 & 5.9 & 0.920 \\
\hline Spain & 506 & 41,974 & 83 & 77 & 20,466 & 3.1 & 11.3 & 4.5 & 7.5 & 0.922 \\
\hline
\end{tabular}

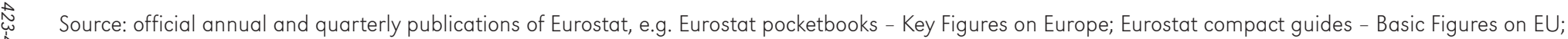
Eurostat Regional Yearbook. 
whole EU different zones could be easily detected: the new States were all below 0.900 (Slovenia included, this time), a figure to compare with the 0.918 in the medium income zone and 0.935 in the high income one.

One last observation is worth noting, in the field of state expenditure on social care, especially when considering education, in fact, in the former socialist states these values were usually higher than those in the states which have long since structured themselves on a capitalist economy.

\section{Before Schengen}

When choosing an intermediate date between 2003-2004 and the most recent available statistics it was easy to choose 2007-2008 for a rather obvious reason. When joining the EU new members were legally obliged to join the Schengen Area in 2007, adopting the relevant rights and obligations. This area is intended as a single country for international travel purposes with a common visa policy. The goal of Schengen Area countries is the elimination of internal border controls with the other Schengen members, while at the same time external border controls with the rest of the world are to be strengthened. This total internal freedom of movement for people was certainly the optimal condition for tourist activities and, also, for workers looking for jobs abroad albeit with some restrictions (Więckowski 2008; Kupiszewski 2008).

For a summary evaluation of change in the EU members (old and new) during the first years after accession, the following table permits one to make some observations. Comparing the crucial data with that in the preceding table, it is evident that the situation has been progressing, and that the differences between old and new members were reducing, even rapidly, in some cases.

Among the new members the population remained nearly unchanged, differences ( + or -) of only a few tens of thousands of people. In the old members on the table, differences remain below $0.5 \%$, with the only exceptions being in the Mediterranean countries, among which the largest change is in Spain with an increase of 2.5 million compared to Table 1 , which is nearly $5 \%$. In all States there appears to be a general movement from the countryside to the towns as the percentage of the urban population is growing everywhere; the birth rate is higher in the countryside than in the cities, as usual, but it is clear that citizens, young and old, are moving to the towns.

The economic field should be subject to deeper analysis because the per capita income in the developed economies showed very strong progress, from $\$ 21,000$ to $\$ 35,000$ : i.e. about $+60 \%$. It is very important to note that inflation in the EU was increasing at the same time from $2.7 \%$ to $5.3 \%$ : nearly doubling in four years, a trend also felt in the new members. But here, leaving inflation aside for a moment, in relative terms the mean growth in income per capita was absolutely exceptional, more than $100 \%$. The most impressive figure was in Latvia, with a growth of $+275 \%$ followed by Estonia $(+258 \%)$. In such company the growth in Slovenia, exactly $100 \%$ is not at all impressive; its figure $(\$ 27,849)$ remaining, in any event, the highest among the new members. More important is that four years beforehand the Slovenian mean per capita income was less than $50 \%$ of the Spanish, but was now reaching $85 \%$ of Spain's. Still it must be said that, notwithstanding the definite improvement of per capita income everywhere in the EU, it has been felt less by populations than would appear from the absolute data since inflation was also high, so purchasing power didn't greatly improve. As a result, the differences between the old and new members have diminished, but the changes have not been as significant as had been hoped.

That part of Gross Domestic Product (GDP) destined to provide state expenditure on social services nearly reverted to the situation of some years before. It appears that the former socialist states took up the example of the capitalist ones, and vice versa: the state contributions lowered in the new members 
Table 2. Main statistical data of the states taken into consideration, 2008

\begin{tabular}{|c|c|c|c|c|c|c|c|c|c|c|}
\hline & $\begin{array}{c}\text { Area } \\
\text { (thous. } \mathrm{km}^{2} \text { ) }\end{array}$ & $\begin{array}{l}\text { Population } \\
\text { (thous.) }\end{array}$ & $\begin{array}{c}\text { Population } \\
\text { density } \\
(\text { per km²) }\end{array}$ & $\begin{array}{l}\text { Urbanization } \\
\qquad(\%)\end{array}$ & $\begin{array}{c}\text { GDP } \\
\text { (USD p.c.) }\end{array}$ & $\begin{array}{c}\text { Inflation } \\
(\%)\end{array}$ & $\begin{array}{l}\text { Unemploy- } \\
\text { ment rate } \\
(\%)\end{array}$ & $\begin{array}{c}\text { GDP for } \\
\text { education } \\
(\%)\end{array}$ & $\begin{array}{l}\text { GDP for } \\
\text { health care } \\
(\%)\end{array}$ & $\mathrm{HDI}$ \\
\hline EU & 4,320 & 496,917 & 115 & 71 & 35,775 & 5.3 & 6.3 & 5.2 & 6.1 & - \\
\hline Czech Republic & 79 & 10,381 & 132 & 75 & 21,027 & 6.3 & 7.5 & 4.4 & 7.4 & 0.885 \\
\hline Estonia & 45 & 1,344 & 30 & 69 & 17,299 & 4.4 & 5.9 & 5.3 & 4.0 & 0.897 \\
\hline Latvia & 65 & 2,271 & 35 & 68 & 14,997 & 11.1 & 7.3 & 5.1 & 5.9 & 0.863 \\
\hline Lithuania & 65 & 3,350 & 51 & 67 & 14,086 & 0.0 & 5.8 & 4.9 & 4.0 & 0.869 \\
\hline Hungary & 93 & 10,147 & 109 & 66 & 15,542 & 6.1 & 7.9 & 5.4 & 5.9 & 0.877 \\
\hline Poland & 313 & 38,135 & 122 & 61 & 13,799 & 4.2 & 7.2 & 5.5 & 4.3 & 0.850 \\
\hline Slovakia & 49 & 5,412 & 110 & 56 & 17,630 & 4.4 & 9.41 & 3.8 & 5.0 & 0.875 \\
\hline Slovenia & 20 & 2,026 & 100 & 50 & 27,849 & 5.7 & 6.7 & 5.8 & 6,1 & 0.923 \\
\hline Austria & 84 & 8,342 & 100 & 67 & 50,098 & 3.2 & 3.9 & 6.1 & 7.2 & 0.951 \\
\hline Denmark & 43 & 5,511 & 125 & 85 & 62,152 & 3.4 & 3.1 & 8.3 & 9.3 & 0.952 \\
\hline Netherland & 43 & 16,486 & 397 & 82 & 52,019 & 2.2 & 3.0 & 5.6 & 7.5 & 0.958 \\
\hline Greece & 132 & 11,216 & 85 & 61 & 32,005 & 4.2 & 7.7 & 4.4 & 5.9 & 0.947 \\
\hline Italy & 301 & 60,045 & 199 & 68 & 38,996 & 3.5 & 6.7 & 4.2 & 6.2 & 0.945 \\
\hline Spain & 506 & 45,454 & 90 & 77 & 35,331 & 4.1 & 11.4 & 4.2 & 7.5 & 0.949 \\
\hline
\end{tabular}

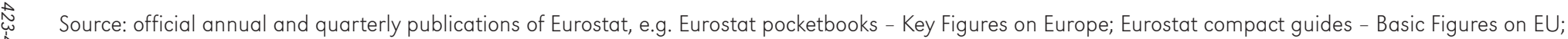
Eurostat Regional Yearbook. 
and increased in the old ones. The changes, anyway, were not significant.

The data on HDI were following a coherent trend in the EU, growing in the new members, as well as in the old. The situation in the very active Slovenia should be noted, now crossing the 0.900 threshold arriving at a very good 0.923 .

The general feeling was that accession to the EU had certainly had a series of impacts, and that the outcomes for the new members had been positive. On 21 December 2007 none of them had doubts: all of them were glad to join the Schengen Area.

\section{After Schengen}

The purpose of the Schengen Area, it has been said, was to eliminate passport controls on Member State citizens when crossing from one Member State to another. In some cases, there are only road signs indicating the presence of a border, without customs controls. After the agreement was signed (on 14 June 1985), all states joining the $\mathrm{EU}$ in the following enlargements also joined the Schengen Area. By contrast the UK and Ireland decided to opt out of the treaty, and for this reason the Schengen rules cannot be in conflict with EU ones. The 4 members of EFTA (European Free Trade Association), Iceland, Norway, Switzerland and Lichtenstein wanted to join Schengen and are now participating as associated states. To complete the information, in 2013 four very new members of the EU were still awaiting the approval of the Schengen experts.

Before analysing the statistical table, including the same states as the preceding ones, it should be said that change in the EU following 2008 was not so much influenced by enlargement of the Schengen Area, but by the global effects of a local unpredicted event, now commonly known as the Lehman-Brothers bankruptcy. Let me stress that the unpredicted event inevitably leading to a world crisis like the one in 1929, could and should have been predicted. In fact, it had been predicted, but it had also been very well hidden. And, apart from LehmanBrothers and some other isolated cases, those principally responsible, that is the executive boards of the major banks, suffered only small, minor consequences.

The conclusions of a comparison of the 2012 Table with the preceding ones are abundantly clear, and the general fall of per capita incomes can really be defined as dramatic.

At first glance, the GDP per capita column demonstrates the key issue in the crisis: the data for the whole EU decreased from $\$ 35,600$ to $\$ 21,200$ and this meant a $34.1 \%$ decrease. Combining this figure with a mean yearly inflation rate of more than $2.5 \%$ means that purchasing power has been reduced by half. In the high income part of the EU the decrease was from more than $\$ 52,000$ to less than $\$ 40,000$, and from $\$ 35,000$ to $\$ 20,000$ in the medium income class.

Everywhere the number of workers diminished parallel with an obvious growth in the number of unemployed. The expense for education remained more or less on the same level; strangely enough, Denmark was forced to make a strong reduction to about one half of the preceding figure.

All this couldn't remain without influence on the HDI, and the data noted a decrease in all states. The data for 2012 were everywhere below those of 2003, and for Slovenia this meant going back below the nearly prestigious zone of 0.900 . And even more amazing is to find not only states like Italy and Spain which always remained in the low category of the EU before enlargement, but also Austria, down under this limit. The title of the last Human Development Report 2013, published by the United Nations Development Programme, is The rise of the South: Human progress in a diverse world (HDI 2013). In the smaller world of the EU and Schengen Area we notice a similar situation: $\mathrm{HDI}$ indices are declining in all states, and the percentage in absolute numbers is measured in values around $32-35 \%$. But comparing the absolute values gives a different impression, and it is better to give some examples comparing the 2012 values not with 2008, (new 
Table 3. Main statistical data of the states taken into consideration, 2012

\begin{tabular}{|c|c|c|c|c|c|c|c|c|c|c|}
\hline & $\begin{array}{c}\text { Area } \\
\text { (thous. } \mathrm{km}^{2} \text { ) }\end{array}$ & $\begin{array}{l}\text { Population } \\
\text { (thous.) }\end{array}$ & $\begin{array}{c}\text { Population } \\
\text { density } \\
(\text { per km²) }\end{array}$ & $\begin{array}{l}\text { Urbanization } \\
\qquad(\%)\end{array}$ & $\begin{array}{c}\text { GDP } \\
\text { (USD p.c.) }\end{array}$ & $\begin{array}{l}\text { Inflation } \\
(\%)\end{array}$ & $\begin{array}{l}\text { Unemploy- } \\
\text { ment rate } \\
(\%)\end{array}$ & $\begin{array}{c}\text { GDP for } \\
\text { education } \\
(\%)\end{array}$ & $\begin{array}{l}\text { GDP for } \\
\text { health care } \\
(\%)\end{array}$ & $\mathrm{HDI}$ \\
\hline EU & 3,970 & 445,662 & 112 & 73 & 21,283 & 2.7 & 8.4 & 4.8 & 7.6 & - \\
\hline Czech Republic & 79 & 10,516 & 132 & 73 & 14,500 & 3.3 & 7.5 & 7.0 & 4.2 & 0.873 \\
\hline Estonia & 45 & 1,340 & 30 & 69 & 12,700 & 4.2 & 10.2 & 5.7 & 4.7 & 0.846 \\
\hline Latvia & 65 & 2,041 & 32 & 68 & 10,900 & 3.2 & 13.3 & 7.3 & 5.1 & 0.863 \\
\hline Lithuania & 65 & 3,007 & 46 & 67 & 11,000 & 3.2 & 13.3 & 5.4 & 4.7 & 0.818 \\
\hline Hungary & 93 & 9,958 & 107 & 70 & 9,800 & 5,7 & 10.9 & 4.9 & 5.0 & 0.848 \\
\hline Poland & 313 & 38,534 & 123 & 61 & 9,900 & 3.7 & 10.1 & 5.2 & 4.8 & 0.821 \\
\hline Slovakia & 49 & 5,410 & 110 & 55 & 13,200 & 3.7 & 14.0 & 4.2 & 5.5 & 0.840 \\
\hline Slovenia & 20 & 2,058 & 100 & 50 & 17,000 & 2.6 & 8.9 & 5.7 & 6.6 & 0.892 \\
\hline Austria & 83 & 8,443 & 101 & 68 & 36,400 & 3.2 & 4.3 & 6.0 & 8.0 & 0.895 \\
\hline Denmark & 43 & 5,603 & 131 & 87 & 43,800 & 7.5 & 7.5 & 3.9 & 8.2 & 0.901 \\
\hline Netherlands & 42 & 16,778 & 404 & 84 & 35,800 & 2.8 & 5.3 & 6.0 & 10.2 & 0.921 \\
\hline Greece & 132 & 11,419 & 87 & 62 & 17,200 & 1.0 & 24.3 & 4.4 & 6.6 & 0.902 \\
\hline Italy & 301 & 59,685 & 198 & 69 & 25,700 & 3.3 & 10.7 & 4.5 & 7.3 & 0.881 \\
\hline Spain & 506 & 46,043 & 91 & 78 & 22,700 & 2.4 & 25.0 & 5.0 & 7.5 & 0.885 \\
\hline
\end{tabular}

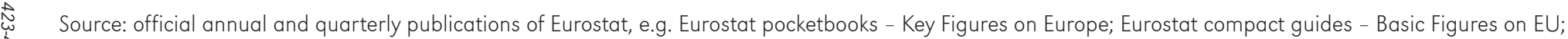
Eurostat Regional Yearbook. 
members in the Schengen Area), but with 2004, their accession to the EU. In \$ terms, Estonia passed from $\$ 5,000$ to $\$ 12,700$; Lithuania from $\$ 5,000$ to $\$ 11,000$; Poland from $\$ 5,000$ to $\$ 10,000$ : even taking in account inflation, citizens had more money in their pockets than before. In the particular case of Poland, those who understand Italian will find the research of Morawski, 2012 very interesting. In the higher income EU States, Dutch citizens passed from $\$ 31,500$ to $\$ 35,800$. In cases like this, inflation had swallowed all of the increase. Not to mention the middle income states, where Greece passed from $\$ 15,500$ to $\$ 17,000$, Spain from $\$ 20,500$ to $\$ 22,700$; and even worse was the situation in Italy: from $\$ 25,000$ to $\$ 25,700$ : in this case the money in the pocket really was less than 4 years before. At a global level, the above-mentioned Human Development Report stresses that the conditions of the poorest are very slowly ameliorating, the richest are getting shamefully better, the middle level is somehow disappearing. All this said, we shall remember that the way of life of the middle classes in the EU and North America is incredibly better than the average standard of living of that of the middle classes of the world. Maybe this observation can be criticised, but the World Bank, the International Monetary fund and the CIA agree that the mean Purchasing Power per Person (not the simple GDP per Person) is $50.000 \$$ in the USA (just a few dollars difference between the three evaluations), while from 30 to 34 Countries have PPP lower than $\$ 2,000$ per year: does anybody dare to think that the standard living of the middle class in the USA and in the poor countries are similar?

But the most important change that followed the new Member States joining the Schengen Area was the free circulation of people. Now, with a simple train ticket and passport, people could freely come to find a job in the EU. This constituted a problem even in the old immigration countries such as France, where the expression "fear of the Polish plumbers" became popular as meaning that, working for a low price, the new immigrant workers from Eastern Europe were leaving their poor French colleagues unemployed. Though obviously exaggerated, the expression was not just a joke; there were some elements of reality. We can consider on the totally positive side of the Schengen agreement the unprecedented agreement in 2011, when Russia accepted to guarantee free circulation of citizens between the Kaliningrad region and the neighbouring Baltic and Polish regions. In the following year the border was crossed more than 2 million times and $\$ 100$ million was spent with a $30 \%$ increase in revenue for shops (Kobrinskaia \& Frumen 2014).

As regards Polish immigration in Italy, it has been following the general trend of immigration from Eastern Europe to the EU, the number of immigrants is growing but at a declining rate: they were 72,457 in 2007, 109,117 in 2010, and the annual increase is now rapidly slowing from more than $10 \%$ to less than $3 \%$. In fact, due to the joint effect of the economic crisis and inflation, life has become more expensive and many recent immigrants are now going back to their native countries.

\section{Conclusion}

The following question was posed in the opening statements of this article: "Did the decision to join the union influence the later socioeconomic development of the East European States?" Before giving the answer (meaning: before giving my personal Italian perspective), I would like to briefly discuss some other issues.

After the disaggregation of the former USSR, Russia remained the second world power after overcoming some years of growing weakness. Since the 1990s the East European states began to consider joining the EU, which eventually happened in 2004. But even during the Cold War years, the Soviet Union had import-export trade with Western Europe. The main western partner was the German Federal Republic, with a total accounting for more than twice the volume of the trade with 
East Germany. Taking an example, the trade Poland had with the USSR and the other European States dependent on it was no higher than that with the rest of the world. USSR, of course, was by far the most important partner, with a volume of import-export trade twice that of West Germany and seven times larger than that with Italy ${ }^{5}$.

Now I'll try proposing an initial answer to the question on the influence of accession on the following socio-economic (maybe better say geographical) developments. In 2012 the Poland-Italy trade was about $\$ 18.6$ billion, about one half that of Poland-Russia ( $\$ 38 \mathrm{bn}$ ). The relevant change is that this is now less than half the Poland-Germany trade which has now reached $\$ 84$ billion (and figures are given in $\$$ or $€$, no longer in Polish Zloty currency). To complete the overview of the situation in Poland, we now find the Czech Republic, UK and, a real new entry, China among the main partners.

In all the new members, total trade registered a twofold or even a threefold increase over the last ten years. Still dominated by the USSR until the early 1990s, the trade arrangements of the East European New Member States are now very varied. Estonia's main partners are now Finland and Russia, while the main partners of the other Baltic Republics are Germany, Russia and the United Kingdom. For the other new members, the main partner is in all cases Germany. Geographical distance has an important impact in determining the remaining partners. In 2004 Hungary's most important partner was Italy, followed by Austria, China, and France; now this has totally changed, and, after Germany, we find Austria, Russia, Romania and Slovakia. Slovakia in turn is strongly linked to the Czech Republic, Poland and Russia in its trade relations, while Slovenia, in a more southerly location, has its principal connections with Italy and Austria.

\footnotetext{
${ }^{5}$ All the following international commerce data are taken from various issues of the yearly Calendario Atlante (Calendar Atlas) published in Novara (Italy) by the geographical publisher De Agostini (in 2014 in its 110th year of publication).
}

As a result of joining the Schengen Area, free circulation of people has now been introduced between Kaliningrad and the Baltic Republics: the outcome of which has been a boost to commercial activity.

In general, we see a different attitude regarding nuclear power production under pressure from environmentalist movements, no new plants have been opened, in the old Member States and many of the old ones are being closed. In contrast nuclear power stations in the Czech Republic, Lithuania, Slovakia, Slovenia and Hungary are still in use, and in some cases their capacity and production are being increased. Still on the issue of energy production, some of the northern New Member States are in favour of using fracking to extract shale-gas, a technique very much used in the USA and Canada in recent years, though not, however, considered environmentally-friendly (Koch 2012).

The situation was really difficult because of the economic crisis, which had already begun long before the official declaration of Lehman-Brothers' bankruptcy. Italy, where some agreements with the Southern Mediterranean States were reducing the dramatic level of seaborne immigration, was totally unprepared to greet the continental newcomers. Italian workers had great difficulties in finding work of any kind. In this difficult situation, Polish newcomers were not totally lost, for instance they even created new jobs. They became 'windscreen cleaners' lurking at traffic lights and jumping with a wet sponge in hand when the red light appeared, cleaning car windscreens in a matter of seconds. Drivers were at the same time shocked by them and somehow admired them so they quite often gave small change to the cleaners. Moreover, Poles were showing an incredible ability to rapidly learn to speak some Italian, which enabled them to ask for more respectable jobs. In a couple of months, many Polish women have become able to speak Italian better than colleagues, who had arrived 2 years earlier from Latin America: consequently they were employed not so much as housekeepers, but as nurses 
for babies or caretakers for old people, jobs needing more speaking ability.

Due to this and their other abilities, after some time many Poles would emigrate once more going to other states of the EU, like France or Germany. Here the new Polish immigrants could find many residents of Polish origin, with recognisable Polish names, and their families, who could possibly give support.

But it is unnecessary to add that for many East Europeans, probably for the majority, the final forbidden dream was clearly one more final emigration: beyond the Atlantic Ocean to the USA or Canada.

This leads to one crucial question: why are the USA and Canada seen as better destinations in comparison with the EU? And to one more question, especially for a citizen of one of the 6 founder states: do we really have an interest in enlarging the Union to include new members? In times of political crisis in Italy the newspapers are today full of articles concerning one particular industrial problem: the Swedish firm Ericsson wants to close a production plant in Italy and move it to Poland as the cost of labour is much less in Poland. Outsourcing of industrial plants is a very serious problem everywhere and is particularly strongly felt in Italy: the system of taxation in Italy is illogical. It might seem incredible, but in Italy the cost of labour is higher than in the rest of Europe, though the real salary received by the employees is below the EU average. This has a double effect producing major conflicts between Italian firms and their workers and, above all, a tendency of firms to undertake outsourcing. The cited case of Ericsson is just the most recent example of this, but many Italian firms had already paved the way, and foreign investments in Italy are very rare.

How can we explain the undeniable tendency of too many EU citizens to move towards USA, Canada or other new destinations? Not only the old destinations like Australia or South Africa: now China, India and Arab countries are taken into consideration, maybe simply as a temporary destination.

The explanation is to be found, in my opinion, in a substantial difference between the
USA and the EU: the former is a Nation, with a strong Federal Government, while the EU is mainly based on a monetary agreement, and has a Central Bank that doesn't have any real power to control the monetary policies of its members. The EU has an elected Parliament, but again with only the power of moral suasion, and no power to impose common policies. The main obstacle is very simple: the Member States don't intend to lose any element of their sovereignty to the Union, and to not do that in different ways. Nearly all agree to maintain their sovereignty in the Europe of markets and the economy, but some want Europe as a competitor to the USA, with Russia as a possible strategic ally, whiles others think that the cold war is still enduring and Russia is only a neighbour of doubtful reliability.

One more opinion of mine: apart from the founders, not all of the old members are really willing to compete with the USA for first position in a globalised world, and I am afraid that many of the New Member States agree with this mindset. And if there is any doubt about EU internal policy being too weak, EU international policy is, without any doubt at all, quite non-existent.

In this situation an alarming anti-European political tendency is growing in many Member States, old and new, and the recent anti-immigration referendum in Switzerland will surely provoke very serious debate: in fact, Switzerland is a member of the Schengen Area and must guarantee free circulation of people.

My maybe utopian wish is to see the EU more firm on its initial purposes, with much stronger institutions, showing a really clear international policy and common actions of social care, so to become a place where everybody will be glad to enter, and even more so to remain 6 .

\footnotetext{
${ }^{6}$ The opinions I expressed are based on a huge flood of essays, press articles, radio and TV broadcasting: I would like to quote some of the ones which have exerted the maximum influence on me. Even before the introduction of the Euro, bitter debates started among the monetary scholars, and are now at a climax. A positive view is expressed by Sorman (2012). Despite being a right-wing thinker, as the majority of today's opposition to the $\mathrm{EU}$, he is rather positive about the action of the
} 
To finish my paper and express my opinion, I think that entering the EU has been a decision more convenient for the more recent members than for the old members, at least until now: probably it will get better for all in the not so far distant future. I admit this is just a hope, not an opinion, but the signs of economic recovery are now detectable?

When in 2012 the EU was awarded the Nobel Prize, many people strongly criticised the decision. But the motivations written by the Committee are well balanced and undeniable:

"The EU is currently undergoing grave economic difficulties and considerable social unrest. The Norwegian Nobel Committee wishes to focus on what it sees as the EU's

\section{References}

Amnesty International, 2006. Investigation on migrant deaths. Statistical Yearbook. London: UNHCR.

Bellezza G., 1974. La Comunità Economica Europea, profilo geografico. Bari: Adriatica Editrice.

BellezzA G., 1978. Geografia. Roma: Editori Riuniti.

BellezzA G., 2009. Lampedusa, primo gradino dell'odierna Odissea mediterranea. Ambiente società territorio: Geografia nelle scuole, vol. 54, no. 3-4, pp. 7-12.

CECOL, 2012. Results of the referendum on the Draft Law Amendments to the Constitution of the Republic of Latvia. Central Elections Commissions of Latvia.

DAVID E., 1993. Facing a holocaust: the Polish government-in-exile and the Jews, 1943-1945. Chapel Hill: University of North Carolina Press Books.

European Central Bank's Director in defending the euro, and is guardedly upbeat relative to the future of the Euro. Feldstein's (2011) opinion by contrast is totally negative and cited in definitive terms. A similar rather unbalanced viewpoint is that of Garton Ash (2012). Balanced information can be found in an article by Tull (2012), where the positions of Robert Mundell, Nobel Prize Winner and main theorist of the euro, and of Allen Meltzer, one of its main opponents, are compared.

7 An increasing number of experts say that the global economic crisis has already reached its nadir and that now clear signs of economic improvement are being seen all around the world. A very interest- most important result: the successful struggle for peace and reconciliation and for democracy and human rights. The stabilising part played by the EU has helped to transform most of Europe from a continent of war to a continent of peace."

"The work of the EU represents 'fraternity between nations', and amounts to a form of the 'peace congresses' to which Alfred Nobel refers as criteria for the Peace Prize in his 1895 will." (Nobelprize 2012).

\section{Editor's Note:}

Unless otherwise stated, the sources of tables and figures are the author(s), on the basis of their own research.

DAVIES N., 2005-2006. God's playground: A history of Poland. In two volumes: Volume 1: The origins to 1795. Volume 2: 1795 to the present. New York: Columbia University Press.

EBERHARDT P., 2002. Ethnic groups and population changes in twentieth-century Central-Eastern Europe. Armonk: M.E. Sharpe.

EU, 2013. Eurostat pocketbooks: European social statistics. Luxembourg: European Union.

FeldStein M., 2011. The failure of the Euro. Foreign Affairs, 13 December.

GARTON AsH T., 2012. The crisis of Europe: How the Union came together and why it's falling apart. Foreign Affairs, 20 August.

Golemo K., Kowalska K., Pittau F., Ricci A. (eds.), 2006. Polonia nuovo paese di frontiera. Da migranti a comunitari. Roma: Caritas Italiana, Centro Studie ricerche-IDOS, pp. 102-111.

ing general vision is exposed by Schwab (2012). There is nothing amazing about his level of information and documentation: Schwab is the founder and Executive Chairman of the World Economic Forum, the Swiss nonprofit organization. Very well-known for its annual winter meeting in Davos, and nowadays gathering more than 2500 participants (private business men and leaders of business companies at highest world level). Also another very interesting contribution is the article by Sen (2012) in The New Republic, a magazine of politics and art commentaries, now completing its 100th year. The author of the article, Amartya Sen, is a Professor in Harvard and Nobel Prize winner. 
GUS, 2012. Poland in figures. Warszawa: Główny Urzad Statystyczny.

HDI, 2013. The rise of the South: Human progress in a diverse world. Human Development Report, UNDP, http://www.undp.org/content/dam/ undp/library/corporate/HDR/2013GlobalHDR/ English/HDR2013\%20Report\%20English.pdf. [16 April 2014].

HRW, 2006. Libya, stemming the flow. Human Rights Watch, vol. 18, no. 5(E), New York.

John Paul II, 2004. Memoria e identità. Milano: Rizzoli.

KobrinskaIA I., Frumen B., 2014. Nessuno conosce noi Russi meglio dei Polacchi. Limes, 2 January, pp. 139-150.

KocH W., 2013. Fracking puts US first in shale gas production. USA Today, 23 October.

KUPISZEWSKI M., 2008. Addressing the irregular employment of migrants - concluding remarks and recommendations [in:] M. Kupiszewski, H. Mattila (eds.), Addressing the irregular employment of immigrants in the European Union: Between sanctions and rights. Budapest: International Organization for Migration, pp. 318-328.

LIMES, 2014. Polonia, I'Europa senza l'Euro. http:// temi.repubblica.it/limes/polonia-leuropa-senzaeuro/56457 [15 April 2014].

MACKINDER H.J., 1904. The geographical pivot of history. Geographical Journal, vol. 23, no. 4, pp. 421-437.

Mehillas O., 2009. L'immigrazione albanese in Italia. Profili sociologici e politiche di controllo. L'Altro Diritto.

MiCHNIK A., 2013. We are bastards of communism. Der Spiegel, 31 July.

Ministero Degli Interni, 2001. Relazione sulla realizzazione degli obiettivi fissati, sui risultati raggiunti e sull'efficacia degli interventi effettuati a sostegno delle Forze di Polizia albanesi (10 /uglio-31 dicembre 2000) presentata al Parlamento dal Ministro dell'Interno Bianco nella XIII legislatura. Document 178, no. 1.
Ministero Degli Interni, 2007. Rapporti sugli immigrati in Italia. Italia. http://www.interno. gov.it/mininterno/export/sites/default/it/assets/ files/15/0673_Rapporto_immigrazione_BARBAGLI.pdf [15 April 2014].

MORAWSKI I., 2012. How Poland became a wealthy country. http://temi.repubblica.it/limes/come-lapolonia-e-diventata-ricca/57070 [15 April 2014].

MoraWski P., 2014. Atlante geopolitico della Polonia. Limes, 10 January.

Nobelprize, 2012. The Nobel Peace Prize 2012 to the European Union (EU) - press release. http:// www.nobelprize.org/nobel_prizes/peace/laureates/2012/press.html [30 April 2014].

SCHWAB K., 2012. The re-emergence of Europe. Koeln: World Economic Forum.

SeN A., 2012. What happened to Europe. The New Republic, 2 August.

SIKORSKI R., 2011. German inaction scarier than Germans in action. The Economist, 29 November.

SoRMAN G., 2012. Why Europe will rise again. The Wall Street Journal, 17 August.

Spinellı A., Rossi E., 2006. // Manifesto di Ventotene. Milano: Mondadori.

TULL S., 2012. Two legends in economics wrestle over the euro's future. CNN Money-Fortune, 9 August.

UNDP, 2011. Development and transition. United Nations Development Programme.

UNHCR, 2006. Piano d'azione per la tutela dei diritti nell'ambito dei flussi migratori. Comunicato Stampa, 10 July, www.unhcr.it [15 April 2014].

VAN ELSUWEGE P., 2004. Russian speaking minorities in Estonia and Latvia: Problems of integration in the threshold of the European Union. European Centre for Minority Issues. Working Paper, 40. Flensburg: ECMI.

Violante A., Vitale A., 2010. L'Europa alle frontiere dell'Unione. Milano: Unicopli.

WIĘCKOWSKI M., 2008. New international mobility of Poles. Espace, Populations, Societes, 2, pp. 261-270. 